\title{
Development of Student Worksheet Based on Problem Based Learning in Office Management Subject
}

\author{
Durinta Puspasari ${ }^{1}$, Durinda Puspasari ${ }^{2}$
}

\begin{tabular}{l} 
ARTICLE INFO \\
\hline Article History: \\
Received 25.12.2018 \\
Received in revised form \\
06.03 .2019 \\
Accepted \\
Available online 01.07 .2019
\end{tabular}

\begin{abstract}
This study aims to analyze the feasibility and response of students to the Problem Based Learning Student Worksheet in the Office Management subject that has been developed. This type of research is Research and Development research using a $4-\mathrm{D}$ model namely Define, Design, Develop, and Disseminate. The subjects in this study were students of the 2016 Class Office Administration Education Department, Faculty of Economics, Universitas NegeriSurabaya, as many as 20 students. Data collection techniques in this study include student worksheet validation sheets based on Problem Based Learning and student response questionnaires. While the data analysis techniques include validation analysis of material experts and linguists, student response questionnaire analysis. The results showed that the results of the material expert validation sheet analysis on Problem Based Learning student worksheets in Office Management subject showed that the percentage of feasibility was $74,29 \%$ seen from the feasibility of content and presentation components and $84 \%$ seen from linguistic componens. While the result response questionnaire analysis showed that the percentage of eligibility was $72 \%$.
\end{abstract}

Keywords:

C IJERE. All rights resenved

Student Worksheet, Problem Based Learning, Office Management.

\section{INTRODUCTION}

Universities as educational institutions are expected to be able to help students develop their potential. To develop the potential of students, the role of lecturers is very important in the learning process, where lecturers are considered capable of realizing changes in student behavior so as to be able to achieve the expected competencies in an effort to improve the quality of learning. With the presence of competencies possessed by the lecturer, it is expected to be able to guide students to independent learning through various learning resources applied in the learning process. The lecturer also acts as a facilitator who is able to provide creative and innovative teaching materials so that students can improve their knowledge and can improve the achievement of the goals and learning process through student w orksheets. Student Worksheet are sheets that contain tasks that must be done by students in the form of instructions, steps to adjust a task that is in accordance with the basic competencies that will be achieved (Depdiknas, 2004). The existence of student worksheet is expected to help students to develop material concepts, considering the Office Management subject is a subject that contains many theories about how to manage all office activities. One of the achievements of learning in Office Management subject is that students are able to master the basic concepts of office management in depth and formulate it in procedural problem solving. From here students are required to be able to analyze cases that often occur in office management.

To support the learning activities contained in the student worksheet based on cases or problems, analysis is needed based on Problem Based Learning. Problem Based Learning is learning that uses real-life (authentic) open-ended problems to be solved by students to develop thinking skills, problem solving skills, social skills, skills for independent learning, and building or gain new knowledge. Based on this, what is meant by Student Worksheet based on Problem Based Learning is a student guide used to share information and discuss to find solutions to problem solving. From here students are required to be critical in solving problems. In PBL, teachers coach students with suggestions for further study or inquiry butdo not assign predetermined learning activities. Instead, students pursue their own prob-lem solutions by clarifying a problem, posing necessary questions, researching thesequestions, and producing a product that displays their thinking. These activities are gen-erally conducted in collaborative learning groups that often solve the same problem indifferent ways and arrive at different answers (Mergendoller, Maxw ell \& Bellisimo, 2006).

\footnotetext{
Corresponding e-mail: durintapuspasari@unesa.ac.id Universitas Negeri Surabaya, orcid.org/0000-0001-9567-7820
}

Universitas Negeri Surabaya 2orcid.org/0000-0002-2177-6954 
Researchers chose the 2016 Office Administration Education Department, Faculty of Economics, Universitas Negeri Surabaya as the subject of research because students in mastering the material in the Office Management subject were still lacking. Students often do not pay attention and talk to themselves with their friends because they feel bored with the material being taught. Students are sometimes sleepy when lecturers are teaching, because lecturers still tend to use lectures in teaching. This study refers to the research journal Pujayanto, et al (2017) whose research results show that the criteria for developing problem based learning materials were the 5 level category when $43.33 \%$ of respondents rated 5 categories of 1 evels and the others gave 4 levels of categories. Furthermore, students who use the material increase and most students have obtained a cognitive value that exceeds the minimum completeness criteria. This research also refers to the research journal Yulia, Buyung \& Relawati (2018) whose research results show that student worksheets based on problem-based learning in numerical material in class VII were declared valid and practically feasible to be used in the learning process by teachers and junior high school students, especially number material.

According to Fathurrohman (2015), learning is a process of thinking. Learning to think emphasizes the process of finding, observing and determining knowledge through interactions between individuals and the environment. While learning is a process carried out by individuals to obtain a new behavior change as a whole, as a result of their own individual experiences in interaction with the environment (Fadillah, 2014). According to Uno (2008), the nature of learning is planning or design as an effort to teach students. Student worksheet are one of the teaching materials that can be used by lecturers in carrying out lecture activities in class. According to Trianto (2014) what is meant by student w orksheet is a student guide that is used to carry out investigation and problem solving activities. Student worksheet are also sheets that contain tasks that must be done by students in the form of instructions, steps to adjust a task that is in accordance with the basic competencies that will be achieved (Depdiknas, 2004). The purpose of this study is analyzing: the feasibility of Student Worksheet Based on Problem Based Learning in Office Management Subject, the response of Student Worksheet Based on Problem Based Learning in Office Management Subject that has been developed.

According to Sani (2014), Problem Based Learning is learning that is delivered by using a way of presenting a problem, asking questions, facilitating an investigation, and opening a dialogue. Problem Based Learning is a learning model that emphasizes students to stimulate learning mindsets through various real problems in daily life, which are connected with the knowledge being learned. The main purpose of Problem Based Learning is not to be used for storing knowledge to students, but must be oriented towards developing critical thinking skills and abilities in problem solving and at the same time developing students' ability to actively build individual know ledge of students (Fathurrohman, 2015).

\section{METHOD}

This type of research is research and development $(\mathrm{R} \& \mathrm{D})$. The product developed in this study is a teaching material in the form of Student Worksheet Based on Problem Based Learning in Office Management Subject. This development research uses a 4-D model. The development model consists of four stages, namely the Define Stage, Design Stage, Develop Stage, Dissemination Stage (Trianto, 2014). The sampling technique used in this study was purposive sampling because researchers determined sampling by specifying specific characteristics that were in accordance with the objectives of the study, namely students of 2016 Office Administration Education Study Program, Department of Economic Education, Faculty of Economics, Surabaya State University as many as 20 students. The data collection technique in this study used Student Worksheet Based on Problem Based Learning validation sheets and student response questionnaires. This study uses validation analysis techniques of material experts and linguists as well as student response questionnaire analysis.

\section{FINDINGS}

\section{Feasibility of Student Worksheet Based on Problem Based Learning in Office Management Subject}

Student Worksheet Based on Problem Based Learning in Office Management Subject for their feasibility are measured through validation sheets from both material experts and linguists as well as student response 
questionnaires. The material expert validation sheet was filled by Office Administration Education lecturers, the language expert validation sheet was filled by Language lecturers, while the student response questionnaire was filled by 20 students of 2016 Office Administration Education Department.

The assessment of the material validator is used to determine the level of feasibility of Student Worksheet Based on Problem Based Learning in Office Management Subject. The level of feasibility of Student Worksheet Based on Problem Based Learning in Office Management Subject assessed includes the feasibility of the content and components of presentation. The recapitulation of the results of the analysis of material expert validation sheets can be presented in Table 1 as follows:

Table 1

Recapitulation of Material Validation Sheets

\begin{tabular}{|c|c|c|c|c|}
\hline Number & Rated Aspect & $\begin{array}{l}\text { Validator } \\
\text { Assessment }\end{array}$ & $\%$ & Criteria \\
\hline \multicolumn{5}{|c|}{ Component of Feasibility to Fill } \\
\hline 1. & Completeness of material & 5 & 100,00 & Very Worthy \\
\hline 2. & Extent of material & 4 & 80,00 & Worthy \\
\hline 3. & Depth of material & 5 & 100,00 & Very Worthy \\
\hline 4. & Features/reliability of features & 4 & 80,00 & Worthy \\
\hline 5. & Accuracy of activities & 4 & 80,00 & Worthy \\
\hline \multicolumn{5}{|c|}{ Presentation Component } \\
\hline 6. & $\begin{array}{l}\text { Systematic consistency of the presentation } \\
\text { in the chapter }\end{array}$ & 5 & 100,00 & Very Worthy \\
\hline 7. & Coherence & 4 & 80,00 & Worthy \\
\hline 8. & $\begin{array}{l}\text { Practice questions at the end of each } \\
\text { chapter }\end{array}$ & 4 & 80,00 & Worthy \\
\hline 9. & $\begin{array}{l}\text { Key answers to practice questions at the } \\
\text { end of the student worksheet }\end{array}$ & 4 & 80,00 & Worthy \\
\hline 10. & $\begin{array}{l}\text { Active involvement of students and } \\
\text { student-centered }\end{array}$ & 5 & 100,00 & Very Worthy \\
\hline 11. & Scientific approach & 4 & 80,00 & Worthy \\
\hline 12. & Variation in presentation & 4 & 80,00 & Worthy \\
\hline \multicolumn{2}{|c|}{ Average Percentage of Assessment } & 52 & 74,29 & Worthy \\
\hline
\end{tabular}

Based on the results of the material expert validation sheet analysis of Student Worksheet Based on Problem Based Learning in Office Management Subject the percentage was $74,29 \%$, so that Student Worksheet Based on Problem Based Learning in Office Management Subject were declared worthy of the feasibility of the content and components of presentation.

While the assessment of the language validator is used to determine the level of feasibility of Student Worksheet Based on Problem Based Learning in Office Management Subject. The level of feasibility of Student Worksheet Based on Problem Based Learning in Office Management Subject assessed includes language components. The recapitulation of the results of the analysis of the language expert validation sheet can be presented in Table 2 as follows: 
Table 2

Recapitulation of Language Validation Sheets

\begin{tabular}{|c|c|c|c|c|}
\hline Number & Rated Aspect & $\begin{array}{l}\text { Validator } \\
\text { Assessment }\end{array}$ & $\%$ & Criteria \\
\hline 1. & $\begin{array}{l}\text { Conformity with the level of development } \\
\text { of student thinking }\end{array}$ & 5 & 100,00 & Very Worthy \\
\hline 2. & $\begin{array}{l}\text { Conformity with the level of social- } \\
\text { emotional development of students }\end{array}$ & 4 & 80,00 & Worthy \\
\hline 3. & Students understanding of the message & 4 & 80,00 & Worthy \\
\hline 4. & $\begin{array}{l}\text { The ability to encourage students to think } \\
\text { critically }\end{array}$ & 5 & 100,00 & Very Worthy \\
\hline 5. & Accuracy of sentence structure & 4 & 80,00 & Worthy \\
\hline 6. & Stiffness of terms & 4 & 80,00 & Worthy \\
\hline 7. & $\begin{array}{l}\text { Linkages between chapters/sub } \\
\text { chapters/sentences/paragraphs }\end{array}$ & 4 & 80,00 & Worthy \\
\hline 8. & Language accuracy & 4 & 80,00 & Worthy \\
\hline 9. & Spelling accuracy & 4 & 80,00 & Worthy \\
\hline 10. & Consistency of using symbols & 4 & 80,00 & Worthy \\
\hline \multicolumn{2}{|c|}{ Average Percentage of Assessment } & 42 & 84,00 & Very Worthy \\
\hline
\end{tabular}

Based on the results of the analysis of the language expert validation sheet of Student Worksheet Based on Problem Based Learning in Office Management Subject the percentage was 84\%, so Student Worksheet Based on Problem Based Learning in Office Management Subject were declared worthy of the linguistic component.

\section{Student Response of Student Worksheet Based on Problem Based Learning in Office Management} Subject

Student responses of Student Worksheet Based on Problem Based Learning in Office Management Subject can be found through questionnaires given to students of the 2016 Office Administration Education Department as many as 20 students. The recapitulation of the results of the student response questionnaire analysis can be presented in Table 3 as follows:

Table 3

\section{Recapitulation of Student Response Questionnaire}

\begin{tabular}{|c|c|c|c|c|}
\hline $\begin{array}{c}\text { Num } \\
\text { ber }\end{array}$ & Rated Aspect & $\begin{array}{c}\text { Student } \\
\text { Assessment }\end{array}$ & $\%$ & Criteria \\
\hline \multicolumn{2}{|l}{ Component of Feasibility to Fill } \\
\hline
\end{tabular}




\begin{tabular}{|c|c|c|c|c|}
\hline 1. & $\begin{array}{l}\text { The material contained in the student } \\
\text { w orksheet is in accordance with the } \\
\text { lecture plan for theSemester Office } \\
\text { Management subject }\end{array}$ & 5 & 100,00 & Very Worthy \\
\hline 2. & $\begin{array}{l}\text { Student w orksheets contain examples that } \\
\text { match the material }\end{array}$ & 4 & 80,00 & Worthy \\
\hline 3. & $\begin{array}{l}\text { Presentation of material on student } \\
\text { w orksheets can motivate students to think } \\
\text { critically }\end{array}$ & 4 & 80,00 & Worthy \\
\hline \multicolumn{5}{|c|}{ Presentation Component } \\
\hline 4. & $\begin{array}{l}\text { Student w orksheets contain coherent, } \\
\text { clear and specific material }\end{array}$ & 4 & 80,00 & Worthy \\
\hline 5. & $\begin{array}{l}\text { Evaluation exercises contained in student } \\
\text { worksheets are able to measure students } \\
\text { ability levels }\end{array}$ & 5 & 100,00 & Very Worthy \\
\hline 6. & $\begin{array}{l}\text { Student w orksheets can help students to } \\
\text { study independently }\end{array}$ & 4 & 80,00 & Worthy \\
\hline \multicolumn{5}{|c|}{ Language Feasibility } \\
\hline 7. & $\begin{array}{l}\text { Student w orksheets use clear and easy to } \\
\text { understand language }\end{array}$ & 4 & 80,00 & Worthy \\
\hline 8. & $\begin{array}{l}\text { The language used in student } w \text { orksheets } \\
\text { can motivate students to read thoroughly }\end{array}$ & 4 & 80,00 & Worthy \\
\hline 9. & $\begin{array}{l}\text { Sentences used in student } w \text { orksheets in } \\
\text { accordance with the rules of good and } \\
\text { correct Indonesian grammar }\end{array}$ & 4 & 80,00 & Worthy \\
\hline 10. & $\begin{array}{l}\text { The sentence order used is in accordance } \\
\text { with the enhanced spelling }\end{array}$ & 4 & 80,00 & Worthy \\
\hline \multicolumn{5}{|c|}{ Feasibility of Integrity } \\
\hline 11. & $\begin{array}{l}\text { The title of the student worksheet can } \\
\text { provide communicative information } \\
\text { about Office Management subject }\end{array}$ & 4 & 80,00 & Worthy \\
\hline 12. & $\begin{array}{l}\text { Giving distance or space in the student } \\
\text { worksheet is clear and makes it easier for } \\
\text { students to study the material }\end{array}$ & 4 & 80,00 & Worthy \\
\hline 13. & $\begin{array}{l}\text { The use of forms and variations of letters } \\
\text { in student w orksheets can increase the } \\
\text { reading appeal of students }\end{array}$ & 4 & 80,00 & Worthy \\
\hline \multicolumn{2}{|c|}{ Average Percentage of Assessment } & 54 & 72,00 & Worthy \\
\hline
\end{tabular}

Based on the results of the questionnaire analysis of Student Worksheet Based on Problem Based Learning in Office Management Subject the percentage was $72 \%$, so Student Worksheet Based on Problem Based Learning in Office Management Subject was declared feasible to use. 


\section{RESULT, DISCUSSION, AND SUGGESTIONS}

\section{Feasibility of Student Worksheet Based on Problem Based Learning in Office Management Subject}

Based on the results of the validation sheet analysis from material experts amounting to $74,29 \%$ and 84\% of linguists of Student Worksheet Based on Problem Based Learning, it can be seen that Student Worksheet Based on Problem Based Learning are feasible for students of 2016 Office Administration Education Department in Office Management subject. This is in accordance with the research conducted by Nugraheni, Salim, \& Sunardi (2017). The results of this study indicate that the group worksheets used for deaf students in science subjects were effectively implemented and could improve students' academic achievement with the initial average score of pretest 43,75 and the final post test score increased by 78,75 . Next is the research conducted by Podolak \& Danforth (2013) which shows that worksheets have proven to be the most preferred learning method for students in modern physics courses. More than two-thirds of the classes tested strongly agree with the student worksheet. So that the results of the survey obtained are ranked 5 out of 5 student w orksheets helping to solve problems in completing homew ork.

Office Management subject are one of the subject in Office Administration Education Department which contains many theories. So students are required not only to understand the material but also to be able to think critically and be able to analyze cases contained in office management. From here we need a Student Worksheet Based on Problem Based Learning. This is in accordance with the opinion (Fathurrohman, 2015) which explains that the main purpose of Problem Based Learning is not to be used for storing know ledge to students, but must be oriented tow ards developing critical thinking skills and abilities in problem solving and at the same time developing students ability to actively build individual knowledge of students (Fathurrohman, 2015). Problem Based Learning based worksheets that are developed of course can be used as a guide for students in working on questions that are tailored to the steps contained in Problem Based Learning. This is in accordance with the opinion (Fathurrohman, 2015) which explains that the steps of Problem Based Learning include: orienting students to real problems, organizing students to learn, guiding individual and group investigations, developing and presenting work, and analyzing and evaluating real problem solving process.

\section{Student Response of Student Worksheet Based on Problem Based Learning in Office Management Subject}

Based on the results of the student response questionnaire analysis of $72 \%$ of Student Worksheet Based on Problem Based Learning, it can be seen that Student Worksheet Based on Problem Based Learning is feasible to be used by 2016 Office Administration Education Department students in Office Management subject. This is supported by research conducted by Asnaini, Adlim \& Mahidin (2016). The learning outcomes of the experimental class students increased by $0,71(70 \%)$ with the criteria of increasing height and the control class increasing by $0,40(40 \%)$ with the category experiencing a moderate increase. While the responses of students to the use of student w orksheet are very good by obtaining the results of $94.32 \%$.

Besides that there is a study conducted by Diniaty \& Atun (2015), where the research adapted from the development model of Borg \& Gall (1983) whose results showed that the response of students to student w orksheet was $90 \%$, while the teacher's response scored $86,65 \%$. Overall, the student worksheet received an assessment with a very good category, so that the products developed in the form of small-scale industry student $w$ orksheet oriented to entrepreneurship chemistry were feasible to be used in learning. There is also research carried out by Syamsurizal, Epinur \& Marzedlina (2014) with the results of research that showed that this non-experimental student worksheet was interesting, easy understood, activating students, and demonstration videos can add insight. So that student worksheet are declared effective and feasible to be used during the learning process. According to students, a lot of work on questions is very necessary to measure the level of students abilities so that students. This is in accordance with the opinion of the Depdiknas (2014) which states that the objectives of student worksheets include: training students to find and develop process skills, as a guide for lecturers and students in carry out the process of learning activities, and help students in obtaining notes of material learned through learning activities. 


\section{REFERENCES}

Asnaini, Adlim \& Mahidin. (2016). Pengembangan LKPD Berbasis Pendekatan Scientific untuk Meningkatkan Hasil Belajar dan Aktivitas Peserta Didik pada Materi Larutan Penyangga. Jurnal Pendidikan Sains Indonesia, 4(2), 191-201.

Departemen Pendidikan Nasional. (2004). Pedoman Umum Pengembangan Bahan Ajar Sekolah Menengah Atas. Departemen Pendidikan Nasional: Direktorat Pendidikan Menengah Umum.

Diniaty, A. \& Atun, S. (2015). Pengembangan Lembar Kerja Peserta Didik (LKPD) Industri Kecil Kimia Berorientasi Kewirausahaan untuk SMK. Jurnal Inovasi Pendidikan IPA, 1(1), 46-56. https://doi.org/10.21831/jipi.v1i1.4531.

Fadillah (2014). Implementasi Kurikulum 2013. Jakarta:Bumi Aksara.

Fathurrohman, M. (2015). Model-model Pembelajaran Inovatif. Jogjakarta: AR-Ruzz Media.

Mergendoller, J. R., Maxwell, N. L. \& Bellisimo, Y. (2006). The efectivenessof problem-based instruction: A comparative study of instructional methods and student characteristics. Interdisciplinary Journal of Problem-Based Learning, 1(2), 49-69.https://doi.org/10.7771/1541-5015.1026.

Nugraheni, P. P., Salim, A. \& Sunardi. (2017). The effectiveness of self-directed learning by using group worksheet in science subjects for hearing impaired students. European Journal of Special Education Research, 2 (2), 73-80. doi: 10.5281/zenodo.242975.

Podolak, K. \& Danforth, J. (2013). The effectiveness of self-directed learning by using group worksheet in science subjects for hearing impaired students interactive modern phy sic w orksheets methodology and assessment. European J of Physics Education, 4(2), 27-31.

Pujayanto, et al. (2017). Development of problem-based learning material for physics mathematics and its implementation. International Journal of Science and Applied Science: Conference Series, 1(1), 16-24. doi: 10.20961/ijsascs.v1i1.51041541-5015.1026.

Sani, R. A. (2014). Pembelajaran Saintifik untuk Implementasi Kurikulum 2013. Jakarta:Bumi Aksara.

Syamsurizal, Epinur \& Marzedlina, D. (2014). Pengembangan Lembar Kerja Peserta Didik (LKPD) Non Eksperimen untuk Materi Keseimbangan Kimia Kelas XI IPA SMAN 8 Muarjo Jambi. J.Ind.Soc.Integ.Chem, 6(2), 35-42.

Trianto. (2014). Mendesain Model Pembelajaran Inovatif, Progresif, dan Kontekstual. Jakarta: Prenada Media Group.

Uno, H. B. (2008). Perencanaan Pembelajaran. Jakata: PT Bumi Aksara.

Yulia, S., Buyung \& Relawati. (2018). Pengembangan Lembar Kerja Siswa (LKS) Berbasis Problem Based Learning pada Materi Bilangan di Kelas VII SMP Negeri 22 Kota Jambi. Jurnal Pendidikan Matematika, 2(1), 192-204. 